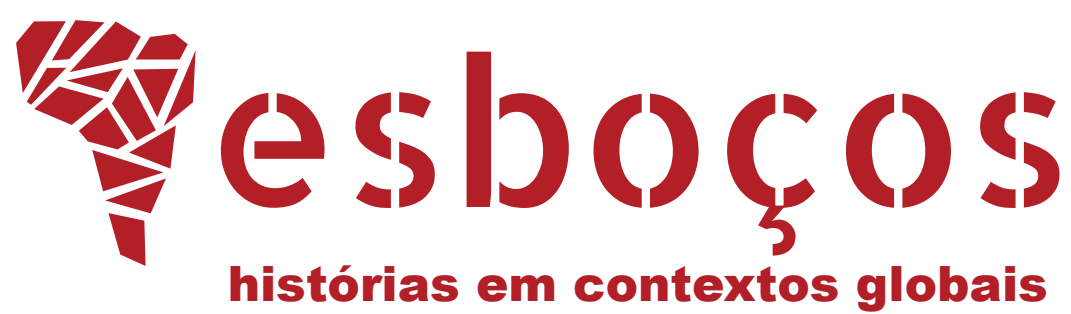

\title{
THE ANTHROPOCENE: A NEW FRAMEWORK OF STUDIES AND ITS LIMITS
}

Ana Carolina Lins Peliz (D) https://orcid.org/0000-0002-3291-0813 Email: anapeliz@gmail.com

a Sorbonne Université, Celsa, Groupe de recherches interdisciplinaires sur les processus d'information et de communication, Paris, France

\section{DEBATE}

Antropoceno, utopia e distopia 


\section{ABSTRACT}

This article is a commentary on an article by Patrícia Vieira published in the current issue of Esboços: histórias em contextos globais, in which the author discusses the thesis that the idea of the annihilation of humanity could be read through the optic of a utopian perspective and not only from a dystopian view in the age of the Anthropocene. She uses the trilogy of the Canadian writer Margaret Atwood, MaddAddam, as an example of her central idea. The theoretical framework is structured around an interdisciplinary study of authors from political sciences, history, sociology and literature. This work is organized in two parts: the first summarizes the main ideas in Vieira's article, and the second proposes a debate about the concept of Anthropocene, its limits and difficulties regarding human and social sciences.

\section{KEYWORDS}

Utopia. Dystopia. Anthropocene. 
ystopia and utopia are present in multiple forms in social and environmental representations. They can be identified in media discourse through their utopian representations of science and nature as opposed to the dystopic failure of the political system (LINS PELIZ, 2017). The same opposition is observed in the discourse of young climate activists, characterized by a profound pessimism about the future of humanity, counter-balanced with a confidence that there is still time for decision-makers to make the right choices and reverse the situation.

Although social discourse seems to be divided between pessimistic and optimistic views, the dystopian idea of collapse, very present in the 70 s, seems to have made a strong comeback. ${ }^{1}$ It has become a tendency to discuss climate change and environmental issues by focusing on its catastrophic consequences and by demonstrating its direct impacts on people's daily lives, such as floods, forest fires, drought and storms (SHIELDS, 2019). The idea that our future is profoundly linked to the planet's future increases the uncomfortable feeling of responsibility or even guilt for the environmental problems. In this context, the possibility of human extinction or at least the breakdown of our capitalist way of life is very much part of the public debate.

Hence the article by Patrícia Vieira (2020), "Utopia and Dystopia in the Age of the Anthropocene", which speaks of the possibility of human annihilation within the framework of dystopian and utopian visions, is an extremely relevant one.

The author defends the thesis that the idea of the annihilation of humanity could be read through the optic of a utopian perspective, and not only from a dystopian view, in the age of Anthropocene. This idea presents a shift in studies about the new millennium, from the idea of a dystopian predominance to a more utopian interpretation. For the author, the predominance of dystopian thought depends on the definition of the term.

The Anthropocene notion would work as a framework for the central idea that a dystopian perspective was once utopian, but the period of time when this Age started is not defined (after industrialized society?). The article is not specific about how exactly utopia and dystopia are shaped by the new age, as the Anthropocene seems to be more used as a given concept, or a broader perspective.

The theoretical framework is structured around an interdisciplinary study of authors specialized in political science (SARGENT, 2013; CLAEYS 2017; JENDRYSIK, 2011), history (GORDIN; TILEY; PRAKASH, 2010), sociology (KUMAR, 2013), literature (JAMESON, 2010) and culture (MOYLAN, 2000). It emphasizes the dominant perspective of different scholars for whom the idea of dystopia seems to have deepened in the first decades of the new millennium.

The first part of this commentary on the article by Patrícia Vieira, attempts to analyse the article, exposing the main ideas, while the second part presents some controversial ideas about the notion of the Anthropocene: why it is important to consider ideology when we explore this notion and how could it work for more than one simple geological age but rather as a framework for studies.

\footnotetext{
${ }^{1}$ Currents of thought about the studies of the risks of the collapse of western society such as the "Collapsology" have seen rapid development in France in the first decade of XXI century. Defined as an interdisciplinary science for one of its main authors, Pablo Servigne, the idea acknowledges media success. Videos of Servigne on the Internet have more than 500,000 views and he is interviewed in mainstream media, and his book Comment tout peut s'effondrer (How everything would collapse) is a best-seller.
} 


\section{CONTEXTUALISATION}

The article has three defined parts. In the first part, Vieira defines dystopia and utopia according to how they have been articulated, stressing the fact that it is not easy to be precise about the difference between the two concepts. Describing both concepts and the views of different scholars, she argues that the origins of the term dystopia can be found in the mid-eighteenth century, but it was already present as a genre in opposition to utopia in the writings of the seventeenth century. She defends the idea that utopia and dystopia have points in common. Both share the same goals and are used to identify the problems of a society in comparison to another, real or imagined. Based on authors such as Moylan and Clayes (in VIEIRA, 2020, p. 353), she distinguishes "anti-utopian dystopia" which precludes any hope for a positive transformation of the present, from "utopian dystopias", that intrinsically possess a minimum of hope for a better future, in spite of their pessimistic presentation of a negative social alternative, and "critical dystopias", texts that have utopianism even in the midst of a dystopian social collapse. Vieira endorses the thoughts of Clayes that the "hopeless dystopias" are profoundly reactionary while "critical dystopias", on the contrary, avoid hopelessness, criticizing the problems of our age at the same time as they offer at least a brief look at potential solutions.

Therefore dystopia, when used as a scientific tool, becomes an instrument of exploration and can promote change. According to Péguinot (1999), based on the thinking of Bachelard and Weber, we need to make future projections to depict the life that we can or want to pursue. The point is to accept that the "can" or "want" are not necessarily a "have to", which would be a reduction of political or scientific ideas into the realm of the moral, even if utopia is always moralistic, because its objective leads to a feeling of guilt, despite the fact that the bounds between science and utopia and the "scientification of utopia" are interesting. On one side, we have new technology and the progress that stems from this offering the possibility to imagine a different future, and on the other side, science is presented as the only entity able to produce solutions for the problems of humanity.

In this part of the article, she also explores the probable reasons why authors had turned, in the last centuries, to dystopianism. Some of the ideas that Vieira enumerates are external, stemming from political or ecological views. She also considers the hypothesis pointed by some authors of the lack of faith for a meaningful change in society. Some other ideas raised by Vieira stem from intrinsic problems of utopianism that tend to lead to oppression, when used as a normative model. She presents the examples of the classless society of communism or the cohesive national community of Nazism. But she refutes this idea and defends that utopianism does not represent an ideal that has to be achieved by all means; "rather, the utopias can operate intrahistorically, forming pockets of resistance and/or opening paths away from what is into a more just polity" (VIEIRA, 2020, p. 7). She assumes that not all utopias necessarily drive us to totalitarianism.

She reminds us of the collapse of grand narratives as a reason for the detachment from utopia. But she argues that the shift from utopia to dystopia is due more to a moral dilemma: what is a good society? Authors are able to identify the problems of our society, but are incapable of finding the solutions, according to Vieira. She also argues that the decline of utopian thoughts and texts could be placed within a condition of mind, where 
humanity is questioning its place on the planet. They even go so far as to question if the existence of humanity is a good thing.

At this point, she moves to the second part of the article, where she shows the twisted movement from utopia to dystopia and vice versa within different periods of literature and specifically related to the idea of human beings as a negative force on Earth. Dystopia is usually represented as a refusal to embrace modern society, in particular, our reliance on science, technology and mechanization, and also the fear of uncontrollable masses and overpopulation. These ideas are the bases for all the theories of population control, arguing that the Earth has limits, and as such, is extremely linked to environmental concerns. The report of Club of Rome (MEADOWS, 1972), The limits to Growth, is a good example.

The relation to technology could be ambiguous, as Vieira points out, for those who have a utopian perspective of modernization, the problem of modern societies remains rooted in the fact that the promises of techno-scientific progress has not yet been fulfilled. The defenders of geo-engineering could be included in this group, for instance, as well as scientists, policy makers and investors who want to promote this Promethean thinking. As Hamilton says (2013), the seduction offered by climate engineering has profound roots: it is integrated into the modernist project of the domination of nature by technological means. On the other side, those who she calls "anti-modern thinkers" don't see modernity in a favourable light, and tend to believe it will lead humanity towards disaster. Modernity is dystopian, and they find refuge in the utopias of pre-modern society.

Vieira places the emergence of the term in the mid-eighteenth century. The modern visions and interpretations of what constitutes a human being and various eschatological modes of thinking, gave way to the idea of the capacity of humankind to create and destroy life, especially with the development of nuclear technology and genetic manipulation in the recent era. In this new era, the destiny of humanity depends on decisions based on self-interest and not according to the will of a divine figure.

According to the author, the necessity to avoid threats to the survival of humanity and the idea of the annihilation of human beings as a negative thing united dystopian and utopian worldviews. But this perspective has changed. For Vieira, in the last decades, the defenders of dystopianism have moved from a consideration of the renunciation of modernity to a complete repudiation of humans as responsible for environmental problems. This shift depends on a vision of human beings as agents that coincides with the contemporary reflections on the Anthropocene that defines humans as a geological force.

Since then, utopians believed that the positive benefits of modernity would extend to all humanity, and progress would save human beings. Anti-modern thinkers preferred not to venture too deeply into this territory, which contemplates the disappearance of humanity, even if it seems to be unavoidable. But since the idea that humanity is responsible for contamination, climate change, annihilation of other species, the belief that the disappearance of human beings might be a positive development takes shape to the point that, according to the author, it assumes a utopian connotation. She presents as examples, activist groups such as Extinction Rebellion or the Voluntary Human Extinction Movement, and also books such as The World Without Us, by the American journalist Alan Weisman, and movies such as The Future is Wild. All these movements and artistic manifestations see humanity as a parasite and promise the salvation of nature, but not of humanity.

But in some ways, a world without human beings is still a final boundary that authors have difficulty in crossing. In the last part of the article, she uses, as an example 
of her central idea, the trilogy of Margaret Atwood, MaddAddam, which includes the novels Oryx and Crake (2003), The Year of the Flood (2009) and MaddAddam (2013). The work of Atwood could be inserted into the traditional and complex representation of nature and the wilderness of the North in Canadian literature (BÜHLER ROTH, 1998). In Atwood's trilogy, humans are eradicated by virtue of a virus created by a scientist and a new species, known as the "crackers", thrives in a post-Apocalyptic world, which is not a hostile place. Nature takes back its rights again. The "crackers", as considered by Vieira, present the idea of a better version of human society and are able to live with a deep connection and respect for the environment. Even though they are different in many aspects from human beings, Crakers are imagined by the author as humanoids and are very like human beings. Atwood would imagine another species of mammal to repopulate Earth, or the scientist in the book could create another creature completely different from human beings, but the author chose a hominid, and, as Vieira points out, toward the end of MaddAddam several Craker-Human children are born, carrying the human genetic heritage forward. It means that humanity is not really extinct.

The question that remains from the literature of Atwood, according to Vieira, is whether the survivor of Homo sapiens is only a matter of choice or is our destiny already decided by the sum total of our bad decisions concerning the environment? The author reminds us that utopias and dystopia are based on the possibility of human beings choosing which society they would build. These elements of volition are, according to the author, central to utopian and dystopian thoughts.

But Atwood presents the idea of starting again from scratch, rather than focusing on extinction, with a new kind of species, created by science; one that is very similar to humanity.

Consider that, as a species, human beings lost their free will and underwent the consequences of their unconscious actions. The annihilation, as described in the book, where human beings are almost extinct, is not a consequence of their own choices. The utopianism of a world without human beings in the Anthropocene would be a possibility. The positive conclusion that the disappearance of our species could be a possibility, gives us a chance to think about our role on Earth.

\section{THE ANTHROPOCENE: A CONTROVERSIAL FRAME OF ANALYSIS}

The main idea of the article is that the sudden, late move away from dystopia to utopia is framed by a specific context and period: the Anthropocene. Nevertheless, the author didn't extend the debate on the definition, origins and the academic controversies around the idea of Anthropocene. The notion of Anthropocene in the article remains very subtle. For example, the author does not provide any definite details about when that historic period starts. If we have entered a new era, the period of history identified by the passage of human activities on Earth, and assuming this footprint is irreversible for the environment, this question compels us to rethink the relationship between societies and nature and, most relevantly, the way that sciences have to work in an interdisciplinary way to imagine how to develop alternative pedagogies to work with the environment faced with an uncertain future.

Actually, this new era is far from being accepted as a given. There are controversies around its historic foundations and the ideology behind the concept. As has already been 
said, the idea of Anthropocene, since its origins, is very linked with the idea of it being possible to change and dominate nature, as preached by the drivers of geo-engineering, even if it has been appropriated by other disciplines.

The notion of Anthropocene was coined by Dutch meteorologist and chemist Paul Crutzen and became stronger at the turn of the XXI century. He won the Nobel Prize for Chemistry in 1995 for his works about the tendency of azote oxide to decompose the ozone layer. He believes that the Anthropocene had already started in the late eighteenth century, when analyses of air trapped in polar ice showed the beginning of growing global concentrations of carbon dioxide and methane. This date also coincides with James Watt's design of the steam engine in 1784. Crutzen defends that the Anthropocene defines the geological epoch, dominated by humans, supplementing the Holocene (the warm period of the past 1-12 millennia) (CRUTZEN, 2002).

Forged by the natural sciences and geology, the notion of Anthropocene causes a certain number of difficulties and the social sciences and humanities have criticized the spreading of the notion.

One of these difficulties could be considered as a semantic problem. The theory creates "the image of a global humanity united by carbon dioxide, thereby erasing the incommensurability of responsibilities" (FRESSOZ, 2014, p. 70). This homogenous idea of "humanity" creates a belief that human beings are equal in their responsibilities and consequences of the possible annihilation of humanity. The work of Atwood presents this idea.

Humanity is a plague to the Earth and this implies that solidarity with our own species is replaced by solidarity with other species and with nature. The anthropocentrism of the notion generates a simplistic misanthropy. Actually, it is not the human being who caused the ecological problem, but the economic and productive model of some societies, which was then imposed on the rest of the world.

Some authors proposed the idea of the Capitalocene (MOORE, 2016) as an alternative to the Anthropocene. But this idea also has its limits. As stressed by Sinaï (2019), capitalism is a necessary explanation for the Anthropocene. It represents a historic dimension of industrialism, but does not explain the fascination for the atom, speed or weapons. On the other hand, countries that promoted "real socialism" also have a responsibility for carbon dioxide emissions. Before the fall of the Berlin wall, East Germany and Czechoslovakia maintained the record for annual emissions of greenhouse gases per person.

The importance of ideology in the construction of the notion of the Anthropocene cannot be ignored in any analysis of the subject. Demos (2017) argues that the terminology works ideologically in support of a neoliberal financialization of nature, anthropocentric political economy, and as an endorsement for geo-engineering as the preferred method of approaching climate change. He defends that to democratize decisions about the world's future, critical scrutiny of the Anthropocene thesis is required in order to develop creative alternatives for the present.

The idea of "volition", which Vieira points out through the example of Atwood's trilogy, is also a central theme for some critics of the Anthropocene. The author and science historian Jean-Baptiste Fressoz (2014), defends the idea that industrialisation took place not in a cognitive void, but in spite of prevailing medical theories emphasising the importance of a wholesome environment and the dangers of pollution. He situates industrialization in a context of consciousness about environmental concerns and the 
preservation of people's health. Fressoz defends replacing the consensual Anthropos with a historically grounded narrative.

The pessimistic prediction about the future of the planet after the industrial revolution already existed at the time of the revolution itself. As Bonnuel and Fressoz (2013) remind us, the French essayist Eugène Huzar predicted in 1857 that for 100 or 200 years factories would produce billions of cubic meters of carbon dioxide and the destruction of the forests would disrupt the planet's balance. The authors question the narrative that promotes the idea of a recent social enlightenment about environmental problems, based on scientific and climatic discoveries, on the bases of the notion of the Anthropocene. For them, the discourse about the new age offers a depoliticization of environmental issues and gives power to those who advocate for the excellence of humanity and geo-engineering.

It is correct to say that in the scientific narrative about the Anthropocene there is a strong and utopian faith in the responses of science. Crutzen for instance, defends that science and technology are responsible for the Anthropocene and they will also present us with the solutions. He is a fervent defendant of geo-engineering to solve the problem, and defends the manipulation of the climate to "optimize" it (CRUTZEN, 2002, p. 23).

In MaddAddams, the solution also came from science; it was the annihilation of humans through a virus and not their salvation. But it was still science. It seems that the new utopian shift reflects the contemporary division in society: the belief in science, more than as a whistle-blower, but as a saving power, and in the meantime, the lack of confidence in political decisions. In real life, this opposition is always present in the discourses of Greta Thunberg, for instance, who calls for humanity, in the face of the inaction by decision makers, to listen to the science and act in favour of the climate.

Nevertheless, the limits and controversies of the Anthropocene haven't reduced the interest in the notion as a framework for thinking and acting about climate change and environmental issues. The opposite is true; it enriches the discussion about the challenges to humanity. As Vieira (2020) says, the reality that our destiny is connected to the things that happen to the planet, and also that the Earth would survive and will continue to exist, despite either our presence or absence, will reorganize the way we conceive of the problem. It means that we can think of the possibility of our extinction, as we think about other species like dinosaurs or mammoths. We are connected to the Earth, but alone in our destiny.

Discourses such as "save the planet" change to "save ourselves" because, Gaia, the Earth, seems to have more capacity for resilience than humans. As scientists are warning, even if our species could dramatically decrease its ecological footprint, it would take thousands of years to return to the same climatic regime as at the time of the Holocene.

The idea of a utopian perspective, regarding the Anthropocene could shed new light on the studies of the environment and representations of nature and help construct new, interesting problems to study. These would include how the Anthropocene idea shapes new discourses, representations and images of nature, people and also resistance, resilience and justice in a world where countries have different responsibilities for environmental issues. There are a lot of problematic issues to be explored under the idea of Dystopia and Utopia in the age of Anthropocene and this gives rise to a renewed perspective of a new field for utopian thought. 


\section{REFERENCES}

BONNUEL, Christophe; FRESSOZ, Jean-Baptiste, L'événement anthropocène: la terre, l'histoire et nous. Paris: Le Seuil, 2013.

BUHLER ROTH, Verena. Wilderness and the Natural Environment: Margaret Atwood's recycling of Canadian Theme. Swiss studies in English Tubinger. Basel: Franck, 1998.

CLAEYS, Gregory. Dystopia: a natural history: a study of modern despotism, its antecedents, and its literary diffractions. New York: Oxford University Press, 2017.

CRUTZEN, Paul J. Geology of mankind. Nature, London, v. 415, January 2002.

FRESSOZ, Jean-Baptiste, Loosing the earth knowingly. In: HAMILTON, Clive; BONNEUIL, Christophe; GEMENNE, François (ed.). The Anthropocene and the global environmental crisis. London: Routledge, 2014. p. 70-83.

GORDIN, Michael; TILLEY, Helen; PRAKASH, Gyan. Introduction: utopia and dystopia beyond space and time. In: GORDIN, Michael; TILLEY, Helen; PRAKASH, Gyan (ed.). Utopia/dystopia: conditions of historical possibility. Princeton: Princeton University Press, 2010. p. 1-17.

HAMILTON, C. Les apprentis sorciers du climat: raisons et déraisons de la géoingénierie. Paris: Seuil, 2013. Electronic version using Kindle.

JAMESON, Fredric. Utopia as method, or the uses of the future. In: GORDIN, Michael; TILLEY, Helen; PRAKASH, Gyan (ed.). Utopia/dystopia: conditions of historical possibility. Princeton: Princeton University Press, 2010. p. 21-44.

JENDRYSIK, Mark. Back to the garden: new visions of posthuman futures. Utopian Studies, Lanham, v. 22, n. 1, p. 34-51, 2011.

KUMAR, Krishan. Utopia's shadow. In: VIEIRA, Fátima (ed.). Dystopia(n) matters: on the page, on screen, on stage. Newcastle upon Tyne: Cambridge Scholars Publishing, 2013. p. 19-22.

MEADOWS, Donella H.; RANDERS, Jorgen (ed.). The limits to growth. Potomac: New York, 1972.

MOORE, Jason W. (ed.). Anthropocene or Capitalocene? Nature, History, and the Crisis of Capitalism. Oakland: PM Press, 2016.

MOYLAN, Tom. Scraps of the untainted sky: science fiction, utopia, dystopia. Boulder: Westview Press, 2000. 
LINS PELIZ, Ana Carolina. Le changement climatique entre utopie et dystopie: une analyse de la représentation du phénomène dans les presses française et brésilienne. Desenvolvimento e Meio Ambiente, Curitiba, v. 40, p. 57-76, April 2017. DOI: http://dx.doi.org/10.5380/dma.v40i0.49072

PÉQUIGNOT, B. Karl Marx: I'utopie, la raison et la sience. Quaderni, Paris, n. 40, p. 97-111, 1999.

SARGENT, Lyman Tower. Do dystopias matter? In: VIEIRA, Fátima (ed.). Dystopia(n) matters: on the page, on screen, on stage. Newcastle upon Tyne: Cambridge Scholars Publishing, 2013. p. 10-13.

SHIELDS, F. Why we're rethinking the images we use for our climate journalism. The Guardian, London, 18 Oct. 2019, Guardian climate pledge, 2019. Available at: https:// www.theguardian.com/environment/2019/oct/18/guardian-climate-pledge-2019images-pictures-guidelines.

SINAÏ, Agnés. Décroissance, écosocialisme: comment répondre à la question écologique? Ballast, Tenir tête, federer, amorcer, n. 7, 17 January 2019.

VIEIRA, Patrícia. Utopia and Dystopia in the Age of the Anthropocene. Esboços, Florianópolis, v. 27, n. 46, p. 350-365, Sept/Dec 2020.

\section{NOTES}

\section{AUTHOR DETAILS}

Ana Carolina Lins Peliz: PhD. Sorbonne Université, Celsa, Groupe de recherches interdisciplinaires sur les processus d'information et de communication, Paris, France.

CORRESPONDING ADDRESS

60 Boulevard Suchet, 75016, Paris, France.

\section{ETHICS COMMITTEE APPROVAL}

Not applicable.

\section{CONFLICT OF INTEREST}

There is no conflict of interest.

\section{LICENSE OF USE}

This article is licensed under the Creative Commons License CC-BY. With this license, you can share, adapt, create for any purpose, as long as the authorship is properly attributed.

\section{PUBLISHER}

Universidade Federal de Santa Catarina. Graduate Program in History. UFSC Journal Portal. The ideas expressed in this article are the sole responsibility of its authors, and do not represent, necessarily, the opinion of the editors or the University.

\section{EDITORS}

Fábio Augusto Morales

Flávia Florentino Varella (Editor-in-chief) 


\section{HISTORY}

Received on: Feb. 14, 2020

Approved on: Aug. 2, 2020

How to cite: LINS PELIZ, Ana Carolina. The Anthropocene: a new frame of studies and its limits. Esboços, Florianópolis, v. 27, n. 46, p. 366-376, set./dez. 2020. 